POLITEKNIK NEGERI NUSA UTARA

\title{
PENGARUH PAKAN MENGANDUNG BAKASANG DALAM MENINGKATKAN PERTUMBUHAN DAN KELANGSUNGAN HIDUP IKAN BAWAL (Colossoma macropomum)
}

\author{
Effects Of Feed Containing Bakasang On The Growth And Survival Rate Of Rawfish \\ (Colossoma macropomum)
}

\author{
Usy Nora Manurung, Edwin Oscar Langi \\ Program Studi Teknologi Budidaya Ikan, Politeknik Negeri Nusa Utara \\ Email: usynoramanurung@yahoo.com
}

\begin{abstract}
Abstrak: Bakasang, produk fermentasi dari jeroan ikan, mengandung Bakteri Asam Laktat (BAL) yang beberapa diantaranya tergolong bakteri probiotik yang dapat meningkatkan pertumbuhan ikan. Penelitian ini bertujuan untuk mengkaji pengaruh pakan mengandung bakasang (PMB) terhadap pertumbuhan dan kelangsungan hidup ikan bawal (Colosoma macropomum) dan menentukan dosis paling efektif dari bakasang terhadap pertumbuhan dan kelangsungan hidup ikan bawal. Sebanyak 120 ekor ikan yang ditempatkan dalam 12 hapa dengan kepadatan 10 ekor ikan/hapa. Setelah proses aklimatisasi, ikan uji diberi PMB dengan empat dosis berbeda $(\mathrm{A}=0 \mathrm{ml} / \mathrm{kg}$ pakan, $\mathrm{B}=50 \mathrm{ml} / \mathrm{kg}$ pakan, $\mathrm{C}=75 \mathrm{ml} / \mathrm{kg}$ pakan dan $\mathrm{D}=100 \mathrm{ml} / \mathrm{kg}$ pakan$)$ dengan tiga ulangan pada masing-masing perlakuan, pada dosis 5\%/bb/hari, diberikan dua kali sehari selama 14 hari. Hasil penelitian menunjukan bahwa pengaruh pemberian pakan meningkat bertambahnya konsentrasi dengan pertumbuhan terbaik teramati pada dosis $100 \mathrm{ml} / \mathrm{kg}$ pakan dengan bertumbuhan sebesar 8.7 gram. Hasil ini memperlihatkan bahwa bakasang merupakan sumber potential probiotik yang dapat meningkatkan pertumbuhan ikan bawal meskipun pengujian dengan periode pemeliharaan lebih lama perlu dilakukan untuk melihat pengaruh optimum dari PMB terhadap pertumbuhan dan kelangsungan hidup.
\end{abstract}

Kata kunci: $\quad$ pertumbuahan ikan, bakasang, Colosoma macropomum

\begin{abstract}
Bakasang, a fermentation product made from fish's viscera, contains Lactic Acid Bacteria (LAB), some of which are probiotic bacteria that can increase fish growth. This study aimed to determine effect of fish feed containing bakasang (FCB) and the effective dose of bakasang on the growth of pomfret (Colosoma macropomum). 120 fish were placed in small net cage (1x1x1) $\mathrm{m}^{3}$. Following acclimatization process, the test fish were fed with four different doses of $\mathrm{FCB}(A=0 \mathrm{ml} / \mathrm{kg}$ of feed, $B=50 \mathrm{ml} / \mathrm{kg}$ of feed, $C=75 \mathrm{ml} / \mathrm{kg} \mathrm{of}$ feed and $D=100 \mathrm{ml} / \mathrm{kg}$ of feed) at a dose of $5 \% / \mathrm{w} /$ day twice a day in triplicate for 14 days. The results showed that the effect of FCB on the pamfret fish growth increased in a dose dependent manner with best growth observed at a dose of $100 \mathrm{ml} / \mathrm{kg}$ of feed with growth of 8.7 gram, suggesting bakasang as potential source of probiotic that can increase the growth of pamfret fish although further study covering longer period time is required to measure the optimum potential of FCB on pamfret fish growth and survival rate.
\end{abstract}

Keyword: $\quad$ fish growth, bakasang, Colosoma macropomum

\section{PENDAHULUAN}

Pakan merupakan salah satu faktor yang berperan penting dalam keberhasilan kegiatan budidaya karena menentukan pertumbuhan dan perkembangan ikan. Ikan membutuhkan makanan dalam jumlah cukup serta berkualitas untuk dapat tumbuh dan berkembang dengan baik (Kordi, 2009). Namun tingginya harga pakan menjadi salah satu masalah karena harga yang semakin tinggi keuntungan yang didapat semakain menyusut. Peningkatan pertumbuhan ikan dapat dilakukan dengan berbagai cara. Salah satu cara untuk meningkatkan pertumbuhan yaitu penambahan probiotik ke pakan ikan. Menurut Ijong dan Ohta (1996), proses fermentasi oleh Bakteri Asam Laktat (BAL) pada bakasang dapat meningkatkan konsentrasi asam-asam amino seperti asam aspartate, asam glutamate, prolin, prolin dan valin. Bakteri Lactobacillus yang terkandung dalam bakasang adalah salah satu bakteri probiotik 
namun tidak semua BAL adalah probiotik (Ingratubun $d k k$. , 2013) sebagai pemicu pertumbuhan ikan. Berdasarkan hal ini maka perlu dilakukan penelitian penggunaan bakasang pada pakan ikan khususnya ikan bawal (Colossoma macropomum) adalah salah satu cara yang baik karena bakasang mengandung bakteri probiotik yang menghasilkan beberapa asam amino yang dapat digunakan sebagai tambahan unsur nutrisi pada pakan untuk memacu pertumbuhan ikan budidaya. Penggunaan bakasang sebagai bahan untuk meningkatkan pertumbuhan telah dilakukan pada ikan nila (Oreochromis niloticus) dan sidat (Anguilla marmorata) (Pangaribuan dkk., 2013 dan Pinoke dkk., 2015). Berdasarkan uraian diatas, perlu dilakukan penelitian untuk mengetahui pengaruh penambahan bakasang pada pakan ikan bawal (C. macropomum).

\section{METODE PENELITIAN}

Penelitian ini dilaksanakan pada Agustus dan September 2020, di kolam budidaya Nahepese Kecamatan Manganitu. Perlakuan bakasang yang digunakan adalah sebagai berikut: $0 \mathrm{ml} / \mathrm{kg}$ pakan, $50 \mathrm{ml} / \mathrm{kg}$ pakan, $75 \mathrm{ml} / \mathrm{kg}$ pakan, $100 \mathrm{ml} / \mathrm{kg}$ pakan. Ikan bawal (Colossoma macropomum) sebanyak 150 ekor dengan berat awal rata-rata 8.7 g. Ikan -diperoleh dari Toko Ikan Atika Jaya Tahuna, yang selanjutnya dibawa ke Nahepese Manganitu. Ikan dimasukan ke dalam 12 hapa berukuran masing-masing $1 \times 1 \times 1 \mathrm{~m}$ dengan kepadatan 10 ekor ikan/hapa. Sebelum diberi pakan perlakuan ikan diaklimatisasi selama satu minggu. Bahan baku: bakasang, pakan pellet tenggelam MG3 merek Comfeed dengan kandungan protein $35 \%$, lemak $5 \%$ dan serat $6,5 \%$.

Proses pembuatan pakan bakasang yaitu pertama pellet Comfeed ditimbang sesuai perlakuan kemudian campur bakasang dan setelah itu dicoating dengan putih telur, setelah itu dikering anginkan suhu ruang selama 24 jam. Ikan diberi makan dua kali sehari yaitu jam 08.00 dan sore 16.00 WITA, (Manurung, $d k k$.,
2013). Data pertumbuhan bawal diukur pada minggu ke dua (hari ke 14). Ikan bawal diambil dari hapa satu persatu menggunakan seser dan dipindahkan ke loyang dan selanjutnya ditimbang. Data pertumbuhan bawal diukur adalah pertumbuhan mutlak yaitu selisih berat bawal pada akhir pemeliharaan dan berat awal ikan. Pertumbuhan mutlak dihitung dengan menggunakan rumus sebagai berikut (Effendie, 1997)

\section{$\Delta \mathbf{G}=\mathbf{W t}-\mathbf{W o}$}

Dimana :

$\Delta \mathrm{G}=$ Pertumbuhan $(\mathrm{g})$

$\mathrm{Wt}=$ Berat ika pada waktu $\mathrm{t}(\mathrm{g})$

Wo $=$ Berat ikan pada awal pemeliharaan $0(\mathrm{~g})$

\section{HASIL DAN PEMBAHASAN}

Pertumbuhan bawal yang diberi bakasang selama dua minggu pemeliharaan dapat dilihat pada Tabel 1. Data pertumbuhan mutlak pada hari terakhir pemeliharaan ditemukan yang terbaik pada perlakuan D bakasang $100 \mathrm{ml} / \mathrm{kg}$ pakan dengan pertumbuhan $8.7 \mathrm{~g}$, diikuti dengan perlakuan C $75 \mathrm{ml} / \mathrm{kg}$ pakan dengan pertumbuhan 8.3 g. Pada perlakuan B pertumbuhan sebesar $6.3 \mathrm{~g}$ sedangkan perlakuan A hanya $4.9 \mathrm{~g}$. Berdasarkan hasil data yang didapat bahwa pemberian bakasang pada pakan ikan bawal dapat meningkatkan pertumbuhan. Dari hasil data yang didapat dapat lihat bahwa semakin banyak dosis yang ditambahkan maka semakin bertambah pertumbuhan ikan.

Menurut Pangaribuan, dkk., (2015), bakasang yang dicampur dengan pakan dengan dosis $100 \mathrm{ml} / \mathrm{kg}$ meningkat pertumbuhan ikan nila sebesar $1.97 \mathrm{~g}$ dibandingkan 0.74 gram untuk kontrol. Hal yang sama dilaporkan oleh Mujiono dkk., (2015) bahwa penambahan bakasang $4 \% / \mathrm{kg}$ pakan pada pakan ikan nila meningkatan pertumbuhan selama pemeliharan empat minggu. Begitu juga yang dilakukan oleh Janis $d k k$., 2016 pertumbuhan ikan sidat mengalami peningkatan setelah diberi bakasang selama proses pemeliharan enam 
minggu dan juga meningkat selama pemeliharanan tiga minggu (Pinoke dkk., 2017). Zhou dkk., (2013) melaporkan bahwa pakan ikan nila yang ditambahkan probiotik Lactocococus lactis selama 40 hari pemeliharaan menunjukan peningkatan berat. Hal yang sama dilakukan oleh Giri dkk., (2013) ikan Labeo rohita yang dipelihara selama 60 hari dengan penambahan probiotik Lactobacillus plantarum dapat meningkatkan efisiensi pemanfaatan pakan dan meningkatkan laju pertumbuhan. Bakteri probiotik yang dikonsumsi masuk ke dalam tubuh melapisi permukaan mukosa usus dan berintraksi dengan sel-sel kekebalan yang ada pada lapisan epitel dan lamina propira saluran pencernaan sehingga proses metabolisme semakin lancar dan nafsu makan meningkat (Pangaribuan $d k k ., 2013)$.

\section{Tabel 1. Data Pertumbuhan Mutlak Ikan Bawal Selama Pemeliharaan}

\begin{tabular}{|c|c|c|c|c|}
\hline No & Perlakuan & $\begin{array}{l}\text { Berat } \\
\text { awal } \\
\text { (W0) }\end{array}$ & $\begin{array}{l}\text { Berat } \\
\text { Akhir } \\
(\mathrm{Wt})\end{array}$ & $\begin{array}{c}\text { Pertumbuhan } \\
\text { berat }(\mathrm{W})\end{array}$ \\
\hline 1 & $\begin{array}{l}\text { A (Kontrol } 0 \\
\mathrm{ml})\end{array}$ & 8.7 & 13.6 & $4.9 \pm 3.05$ \\
\hline 2 & $\begin{array}{l}\text { B (Bakasang } 50 \\
\mathrm{ml})\end{array}$ & 8.7 & 15 & $6.3 \pm 2.53$ \\
\hline 3 & $\begin{array}{l}\text { C (Bakasang } 75 \\
\mathrm{ml})\end{array}$ & 8.7 & 17 & $8.3 \pm 1.85$ \\
\hline 4 & $\begin{array}{l}\text { D (Bakasang } \\
100 \mathrm{ml})\end{array}$ & 8.7 & 17.3 & $8.6 \pm 1.85$ \\
\hline
\end{tabular}

\section{KESIMPULAN}

Pemberian pakan dengan penambahan bakasang dapat meningkatkan pertumbuhan. Dosis terbaik dihasilkan pada $100 \mathrm{ml} / \mathrm{kg}$ pakan yang ditunjukan dengan pertambahan berat bawal (C. macropomum) $8.6 \mathrm{~g}$ selama masa pemeliharaan dua minggu.

\section{DAFTAR RUJUKAN}

Effendi H. 1997. Biologi Perikanan. Yayasan Pustaka Nusatama. Yogyakarta.

Giri, S., Sankar F., Sukumaran and Oviya, M. 2013. Potential probiotic (Lactobacillus plantarum) VSG3 improves the growth, imunity and disease resistance of tropical freshwater fish (Labeo rohita). Fish and Shellfish Imunoligy Journal, 23 (2), pp. 660-666

Ijong F. and Otha. 1996. Psyhochemical and Microbiology Changes Associated With Bakasang. Processing - A Traditional Indonesian Fermented Fish Sauce. Juornal of the Science of Food and Agriculture. 71, pp 6974

Ingratubun J, Aquarista, Ijong Frans and Onibala Hens. 2013. Isolation and identification of lactic acid bacteri in bakasang as fermentedmicrobe starter. Aquatic Science \& Manajemen, Edisi Khusus 1. $58-56$

Janis, O. A. P., Tumbol, R. A dan Londong, S. 2016. Efikasi Bakasang sebagai imunostimulan pada pakan sidat (Anguilla marmorata) terhadap infeksi Aeromonas hydrophila. Ejournal Budidaya Perairan 4 (2): 37-43

Kordi, G. 2009. Budi Daya Perairan. Buku kedua. PT Citra Aditya Bakti. Bandung.

Manurung UN. Manoppo H, Tumbol RA. 2013. Evaluation of Baker's Yeast (Saccharomyces cereviciae) In Enhancing Non Specific Immune Response and Growth of Nile Tilapia (Orechromis niloticus). Ejournal Budidaya Perairan 1 (1) : 814.

Mujiono F., Sampekalo J., dan Lumenta C. 2015. Pertumbuhan Benih Ikan Nila (Oreochromis niloticus) dengan Menggunakan Pakan Komersil yang Diberi Tambahan "Bakasang”. EJournal Budidaya Perairan 3 (1): 187-194 
Pangaribuan R. D., Tumbol R. A., Manoppo H. and Sampekalo J. 2013. The Role of Bakasang as immunostimulant on non-specific immune response in Nile Tilapia (Oreochromis niloticus). Aquatic Science \& Management Journal. No.2

Pinoke S. A. K., Tumbol R.A. dan Kolopita M. E. F. 2015. Penambahan Bakasang Pada Pakan Benih Sidat (Anguilla marmorata) untuk meningkatan sistem imun non spesifik. Budidaya Perairan. 3 (3): 12-18.
Zhou F. Zhongdian D. Yong F, Tongming L, Yongqing Z, Xiangshan J, Weiyun C. Jiao Z, Hui W. 2013. Molecular cloning, genomic structure, polymorphism and expression analysis of major histocompatibility complex class II $B$ gene of tilapia (Oreochromis niloticus). Journal Aquaculture. 327-375, 149-157 page. 